\title{
The Warthin-Like Variant of Papillary Thyroid Carcinoma: A Comparison with Classic Type in the Patients with Coexisting Hashimoto's Thyroiditis
}

\author{
Min-kyung Yeo, ${ }^{1,2}$ Ja Seong Bae, ${ }^{3}$ Sohee Lee, ${ }^{3}$ Min-Hee Kim, ${ }^{4}$ \\ Dong-Jun Lim, ${ }^{4}$ Youn Soo Lee, ${ }^{1}$ and Chan Kwon Jung ${ }^{1}$ \\ ${ }^{1}$ Department of Hospital Pathology, College of Medicine, The Catholic University of Korea, Seoul 137-701, Republic of Korea \\ ${ }^{2}$ Department of Pathology, Chungnam National University School of Medicine, Daejeon 301-747, Republic of Korea \\ ${ }^{3}$ Department of Surgery, College of Medicine, The Catholic University of Korea, Seoul 137-701, Republic of Korea \\ ${ }^{4}$ Department of Internal Medicine, College of Medicine, The Catholic University of Korea, Seoul 137-701, Republic of Korea \\ Correspondence should be addressed to Chan Kwon Jung; ckjung@catholic.ac.kr
}

Received 17 October 2014; Revised 2 April 2015; Accepted 8 April 2015

Academic Editor: Jack R. Wall

Copyright (C) 2015 Min-kyung Yeo et al. This is an open access article distributed under the Creative Commons Attribution License, which permits unrestricted use, distribution, and reproduction in any medium, provided the original work is properly cited.

\begin{abstract}
Background. The Warthin-like variant of papillary thyroid (WLPTC) is a rare subtype of papillary thyroid carcinoma (PTC) resembling Warthin tumors of the salivary glands. Due to its rarity, the clinicopathologic and molecular features of WLPTC remain unclear. Methods. Of the 2,139 patients who underwent surgical treatment for PTC from 2012 to 2013, 40 patients with WLPTC were identified and compared to 200 consecutive patients with classic PTC. BRAF mutation was tested with pyrosequencing. Results. There were no significant differences in age, predilection for women, multifocality, extrathyroidal extension, or lymph node metastasis between WLPTC and classic PTC. However, WLPTCs were more commonly associated with Hashimoto's thyroiditis than classic PTCs (93\% versus 36\%, resp., $P<0.001)$ and showed significantly lower rate of $B R A F$ mutation when compared to classic PTCs $(65 \%$ versus $84 \%$, resp., $P=0.007)$. In classic PTC, the frequency of $B R A F$ mutations was negatively correlated with coexisting Hashimoto's thyroiditis. When we compared WLPTC and classic PTC in the patients with coexisting Hashimoto's thyroiditis, there were no significant differences in clinicopathologic characteristics or the BRAF mutational rate between the two groups. Conclusions. Patients with WLPTC have similar demographic, clinical, pathologic, and molecular characteristics to those with classic PTC coexisting with Hashimoto's thyroiditis.
\end{abstract}

\section{Introduction}

Papillary thyroid carcinoma (PTC) is the most common malignant neoplasm of the thyroid gland and many variants of PTC have been described including classic, follicular, tall cell, diffuse sclerosing, solid, oncocytic, columnar cell, cribriformmorular, and clear cell variants [1]. Most PTCs have a good prognosis, but some PTC subtypes such as tall cell, columnar cell, and hobnail variants have a more aggressive clinical course [1-3]. The Warthin-like variant of PTC (WLPTC) is a rare variant of PTC that is considered to be a subtype of the oncocytic variant [1]. It has papillary or follicular structures lined by oncocytic cells showing typical PTC nuclear features and marked lymphoplasmacytic infiltration of the stroma. Since WLPTC was first described in 1995, it has generally been considered having similar or less aggressive clinical behavior to classic PTC [4-6]. However, published studies on WLPTC include only a few case reports with short follow-up, and the pathological characteristics and clinical behavior of WLPTCs have not been well documented.

WLPTCs are commonly associated with lymphoid infiltration in tumoral and nontumoral areas, and some authors considered this an implication of favorable prognosis [7]. Recent studies on the coexistence of Hashimoto's thyroiditis (HT)/chronic lymphocytic thyroiditis in PTCs have reported less aggressive pathologic features with better long-term 


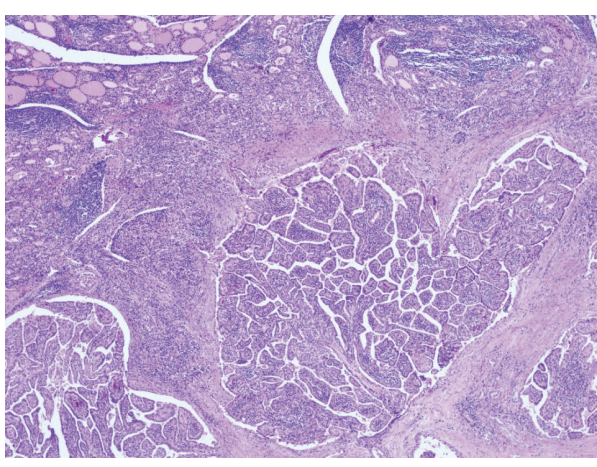

(a)

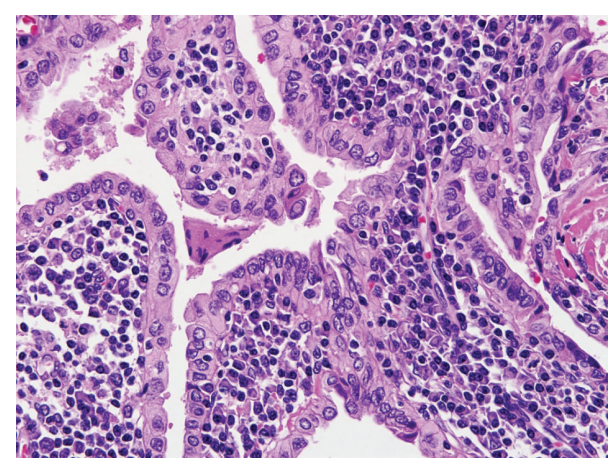

(b)

FIgURE 1: The Warthin-like variant of papillary carcinoma is associated with chronic lymphocytic (Hashimoto) thyroiditis. (a) The tumor shows well-developed papillae with dense lymphoplasmacytic infiltration of the stalks. The surrounding normal thyroid parenchyma exhibits Hashimoto's thyroiditis. (b) Tumor cells have granular oncocytic cytoplasm and nuclear features of papillary carcinoma including optically clear nuclei, nuclear grooves, and intranuclear pseudo-inclusions. A dense infiltration of lymphoplasma cells is seen in the stalk of papillary structures.

outcome than PTCs without HT [8-10]. Thus, we postulated that WLPTC, frequently accompanied by HT, might have a different prognosis from classic PTC. To date, there has not been a study comparing the clinicopathologic behavior of WLPTC with that of classic PTC. The aim of this study was to investigate the demographic, clinical, and molecular characteristics of patients with WLPTC, classic PTC, and classic PTC with coexisting HT to evaluate prognostic factors for WLPTC.

\section{Materials and Methods}

We performed a retrospective review of database of patients with PTC under approval by the Institutional Review Board of The Catholic University of Korea, Seoul St. Mary’s Hospital.

2.1. Patients. A total of 2,139 patients underwent surgical treatment and were histologically confirmed to have PTC at Seoul St. Mary Hospital between January 2012 and December 2013. Of these, 40 (1.9\%) who were diagnosed with WLPTC were enrolled and 200 consecutive patients with classic PTC were selected as controls. Ipsilateral central neck lymph node dissection was routinely performed in all patients. HT was diagnosed based on histologic findings of the thyroid; peritumoral lymphocytic infiltration alone was excluded. All histologic and cytolopathologic slides were reviewed by three experienced pathologists (Chan Kwon Jung, Min-kyung Yeo, and Youn Soo Lee) with a special interest in thyroid pathology. Consensus was reached on all cases.

2.2. Fine Needle Aspiration Cytology. All thyroid fine needle aspiration cytology (FNAC) was performed under ultrasound guidance by experienced radiologists and processed with the ThinPrep preparation method. We classified the FNAC samples according to the Bethesda system for reporting thyroid cytopathology [11].
2.3. BRAF V600E Mutation Analysis. Tumor areas were manually microdissected from two or three $10-\mu \mathrm{m}$ thick deparaffinized tissue sections under a stereomicroscope. Genomic DNA was extracted from the dissected tissue samples using the QIAamp DNA Mini Kit (Qiagen, Hilden, Germany). WLPTC has abundant lymphoplasmacytic infiltration within the tumor (Figure 1). Contamination of a tumor sample by normal cells can lead to false negativity on somatic mutation analysis; therefore, we used pyrosequencing to detect $B R A F$ V600E mutation, because pyrosequencing is more sensitive than Sanger sequencing and has similar sensitivity to realtime PCR method $[12,13]$. Pyrosequencing was performed on the Pyromark Q24 platform (Qiagen) as described previously [12].

2.4. Statistical Analysis. Pearson's chi square and Fisher's exact tests were used to evaluate the relationship between categorical variables, while Student's $t$-tests and Mann-Whitney $U$-tests were used to compare two different groups of continuous parametric data. Statistical analysis was performed with SPSS software (Version 16.0, SPSS, Chicago, IL, USA).

\section{Results}

3.1. Clinicopathologic Characteristics of PTC Patients according to Histologic Subtype. The clinicopathologic characteristics of 40 WLPTC and 200 classic PTC patients are summarized in Table 1. The median age at surgery for WLPTC and classic PTC patients was 46 years and 45 years, respectively, with no significant difference between groups. The WLPTC patients had larger tumor size (median: $1.0 \mathrm{~cm}$, ranged from 0.4 to $2.2 \mathrm{~cm}$ ) than classic PTC patients (median: $0.7 \mathrm{~cm}$ ) $(P=0.043)$. HT more frequently coexisted with WLPTC than classic PTC (93\% versus 36\%, resp., $P<0.001$ ). There were no significant differences in multifocality, extrathyroid extension, pathologic (p) $\mathrm{T}$ stage, lymph node metastasis, 
TABLE 1: Comparison of clinicopathologic characteristics between WLPTC and classic PTC.

\begin{tabular}{|c|c|c|c|}
\hline Characteristic & Classic PTC $(N=200)$ & WLPTC $(N=40)$ & $P$ value \\
\hline Mean age (years) & $45(22-73)$ & $46(18-77)$ & 0.595 \\
\hline Age & & & 0.729 \\
\hline$<45$ & $94(47 \%)$ & $17(43 \%)$ & \\
\hline$\geq 45$ & $106(53 \%)$ & $23(58 \%)$ & \\
\hline Sex & & & 0.374 \\
\hline Female & $161(81 \%)$ & $35(88 \%)$ & \\
\hline Male & $39(20 \%)$ & $5(13 \%)$ & \\
\hline Multifocality & & & 0.385 \\
\hline Unifocal & $108(54 \%)$ & $25(63 \%)$ & \\
\hline Multifocal & $92(46 \%)$ & $15(38 \%)$ & \\
\hline Surgery type & & & 0.088 \\
\hline Lobectomy & $63(32 \%)$ & $7(18 \%)$ & \\
\hline Total thyroidectomy & $137(69 \%)$ & $33(83 \%)$ & \\
\hline Median tumor size $(\mathrm{cm})$ & $0.7(0.2-4.5)$ & $1.0(0.4-2.2)$ & 0.043 \\
\hline pT stage & & & 0.134 \\
\hline pT1 & $123(62 \%)$ & $30(75 \%)$ & \\
\hline pT2 & $2(1 \%)$ & $1(3 \%)$ & \\
\hline pT3 & $75(38 \%)$ & $9(23 \%)$ & \\
\hline Extrathyroidal extension & & & 0.073 \\
\hline Absent & $125(63 \%)$ & $31(78 \%)$ & \\
\hline Present & $75(38 \%)$ & $9(23 \%)$ & \\
\hline pN stage & & & 0.730 \\
\hline $\mathrm{pN} 0$ & $102(51 \%)$ & $22(55 \%)$ & \\
\hline $\mathrm{pN} 1$ & $98(49 \%)$ & $18(45 \%)$ & \\
\hline Hashimoto's thyroiditis & & & $<0.001$ \\
\hline Absent & $147(74 \%)$ & $8(20 \%)$ & \\
\hline Present & $53(27 \%)$ & $32(80 \%)$ & \\
\hline Preoperative diagnosis & & & 0.697 \\
\hline Atypia of undetermined significance & $7(4 \%)$ & $2(5 \%)$ & \\
\hline Suspicious for PTC & $45(23 \%)$ & $7(18 \%)$ & \\
\hline PTC & $148(74 \%)$ & $31(78 \%)$ & \\
\hline$B R A F$ mutation & & & 0.015 \\
\hline Absent & $33(17 \%)$ & $14(35 \%)$ & \\
\hline Present & $167(84 \%)$ & $26(65 \%)$ & \\
\hline
\end{tabular}

PTC, papillary thyroid carcinoma; WLPTC, Warthin-like variant of papillary thyroid carcinoma.

or preoperative diagnosis between the two groups (Table 1). However, the BRAF V600E mutation rate was significantly lower in WLPTC than in classic PTC (65\% versus $84 \%$, resp., $P=0.015)$. Classic PTC coexisting with HT showed a significantly lower $B R A F$ mutational rate than that without HT (74\% versus $87 \%$, resp., $P=0.031$ ). However, there were no significant differences in clinicopathologic features between classic PTC patients with or without HT (Table 2).

\subsection{Clinicopathologic Characteristics of WLPTC and Classic} PTC in Patients with Coexisting Hashimoto's Thyroiditis. When we compared WLPTC and classic PTC in patients with coexisting Hashimoto's thyroiditis, there were no significant differences in age, sex, multifocality, tumor size, pT stage, extrathyroidal extension, lymph node metastasis, preoperative diagnosis, or BRAF V600E mutation (Table 3).
3.3. Clinicopathologic Characteristics of Microcarcinomas $(\leq 1.0 \mathrm{~cm}$ in Size) according to Histologic Subtype. There were no significant differences in age, sex, multifocality, pT stage, extrathyroidal extension, lymph node metastasis, preoperative diagnosis, or BRAF V600E mutation (Table 4). WLPTC microcarcinoma patients had larger tumor size (mean: $0.7 \mathrm{~cm}$ ) than classic PTC microcarcinoma patients (mean: $0.6 \mathrm{~cm})(P=0.001)$. HT more frequently coexisted with WLPTC than with classic PTC (96\% versus 35\%, resp., $P<$ $0.001)$.

\section{Discussion}

The presence of HT in PTC has been associated with favorable prognostic features, such as lower rates of lymph node metastasis, extrathyroidal extension, and TNM stage, and lower 


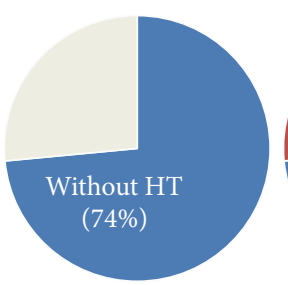

(A) Classic variant without HT

\begin{tabular}{lcc}
\hline & $(\mathrm{A})$ versus $(\mathrm{B})$ & $(\mathrm{B})$ versus $(\mathrm{C})$ \\
\hline Age & $=$ & $=$ \\
Female & $<$ & $=$ \\
Tumor site & $=$ & $=$ \\
Multifocality & $=$ & $=$ \\
Tumor size & $=$ & $=$ \\
pT stage & $=$ & $=$ \\
Extrathyroidal extension & $=$ & $=$ \\
pN stage & $=$ & $=$ \\
BRAF mutation & $>$ & $=$ \\
& &
\end{tabular}

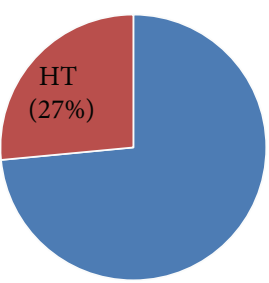

(B) Classic variant with HT

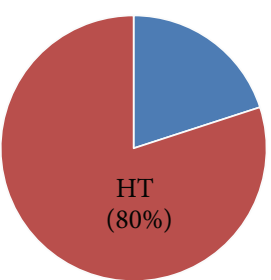

(C) Warthin-like variant

FIgURE 2: A schematic diagram summarizing the relationship between the Warthin-like variant of papillary carcinoma and classic papillary carcinomas with or without Hashimoto's thyroiditis according to clinicopathologic features.

frequency of BRAF V600E mutation [8, 9, 14-18]. The peculiar lymphoid infiltrates in the papillary stalks suggest that WLPTC might have a distinguished entity [7]. WLPTC is commonly accompanied by HT in a background [19]. In the present study, HT was seen in $80 \%$ of all WLPTC cases. We hypothesized that WLPTC might have better prognosis than classic PTC due to an association with HT. However, there were no significant differences in clinicopathologic factors (age, sex, multifocality, pT stage, extrathyroid extension, and lymph node metastasis) except for tumor size, HT, and $B R A F$ mutation between WLPTC and classic PTC. When we compared WLPTC and classic PTC with HT only, there were no significant differences in age, sex, multifocality, $\mathrm{pT}$ stage, extrathyroid extension, lymph node metastasis, or even tumor size or BRAF V600E mutation between groups. Thus, we suggest that the pathologic and clinical behaviors of WLPTCs are similar to those of classic PTC, especially classic PTC with HT (Figure 2).

Despite the fact that BRAF mutations have been found in $>80 \%$ of classic PTC [20], data on mutation frequencies are only available from a small series of WLPTCs: $6 / 8$ (75\%), $2 / 2$ (100\%), $2 / 3$ (67\%), and 0/3 (0\%) [21-24]. In our study, the BRAF V600E was found in $26(65 \%)$ of 40 patients with WLPTC. There was no relationship between BRAF V600E status and clinicopathologic features (age, sex, tumor size, multifocality, extrathyroidal extension, pT stage, and lymph node metastasis) in WLPTC (data not shown).

The prevalence of WLPTC was $1.9 \%(40 / 2,139)$ of all PTCs in our study population. However, it seems that the incidence has been underestimated because WLPTCs are often misclassified as classic, tall cell, or oncocytic variants [3]. In a recent Korean study, Jun et al. reported $16(0.2 \%)$ WLPTCs of 8,179 PTCs [25]. Although classic PTC and WLPTC show a similar growth pattern, the papillary cores of the classic variant do not show marked infiltration of lymphocytes and plasma cells $[3,26]$. Because tumor cells of WLPTC have abundant eosinophilic cytoplasm, the differential diagnosis includes tall cell and oncocytic (Hürthle cell) variants of PTC (Figure 3 ). The tall cell variant consists of $\geq 50 \%$ tall cells. Tall cells have a height at least twice their width with a dense eosinophilic cytoplasm and prominent cell borders $[3,20,27]$. Tall cell variants often exhibit closely packed papillae and thin elongated follicles [20]. In the oncocytic variant, tumor cells show dense eosinophilic, granular cytoplasm and the typical nuclear features of PTC [3]. In tall cell and oncocytic variants, papillary structures do not have dense infiltration of lymphoplasma cells in their stalks.

The cytologic diagnosis of WLPTC may be difficult due to an abundant lymphoid background and oncocytic change in tumor cells [28]. In our study, there was no difference in FNAC results between classic PTCs and WLPTCs. As the ThinPrep method filters inflammatory cells in thyroid FNAC samples, obscured lymphocytes and plasma cells are markedly decreased in the liquid-based preparation when compared with conventional smears (Figure 4). Thus, cytomorphology could be easily detected in WLPTCs using ThinPrep.

The limitations of our study include its retrospective design and lack of follow-up to estimate patient prognosis.

In conclusion, patients with WLPTC had similar demographic, clinical, pathologic, and molecular characteristics to those with classic PTC coexisting with HT. Further long-term follow-up studies are necessary to confirm the biologic behavior and prognosis of WLPTC. 
TABLE 2: Comparison of clinicopathologic characteristics between classic PTC with or without HT.

\begin{tabular}{|c|c|c|c|}
\hline Characteristic & Classic PTC with HT $(N=53)$ & Classic PTC without HT $(N=147)$ & $P$ value \\
\hline Median age (years) & $46(25-73)$ & $45(22-73)$ & 0.357 \\
\hline Age & & & 0.261 \\
\hline$<45$ & $21(40 \%)$ & $73(50 \%)$ & \\
\hline$\geq 45$ & $32(60 \%)$ & $74(50 \%)$ & \\
\hline Sex & & & $<0.001$ \\
\hline Female & $52(98 \%)$ & $109(74 \%)$ & \\
\hline Male & $1(2 \%)$ & $38(26 \%)$ & \\
\hline Multifocality & & & 0.264 \\
\hline Single & $25(47 \%)$ & $83(57 \%)$ & \\
\hline Multiple & $28(53 \%)$ & $64(44 \%)$ & \\
\hline Surgery type & & & 0.122 \\
\hline Lobectomy & $12(23 \%)$ & $51(35 \%)$ & \\
\hline Total thyroidectomy & $41(77 \%)$ & $96(65 \%)$ & \\
\hline Median tumor size $(\mathrm{cm})$ & $0.7(0.3-4.5)$ & $0.6(0.2-3.3)$ & 0.343 \\
\hline pT stage & & & 0.532 \\
\hline pT1 & $34(64 \%)$ & $89(61 \%)$ & \\
\hline pT2 & $1(2 \%)$ & $1(1 \%)$ & \\
\hline pT3 & $18(34 \%)$ & $57(39 \%)$ & \\
\hline Extrathyroidal extension & & & 0.620 \\
\hline Absent & $35(66 \%)$ & $90(61 \%)$ & \\
\hline Present & $18(34 \%)$ & $57(39 \%)$ & \\
\hline $\mathrm{pN}$ stage & & & 0.262 \\
\hline pN0 & $31(59 \%)$ & $71(48 \%)$ & \\
\hline $\mathrm{pN} 1$ & $22(42 \%)$ & $76(52 \%)$ & \\
\hline Preoperative diagnosis & & & 0.904 \\
\hline Atypia of undetermined significance & $2(4 \%)$ & $5(3 \%)$ & \\
\hline Suspicious for PTC & $13(25 \%)$ & $32(22 \%)$ & \\
\hline PTC & $38(72 \%)$ & $110(75 \%)$ & \\
\hline$B R A F$ mutation & & & 0.031 \\
\hline Absent & $14(26 \%)$ & $19(13 \%)$ & \\
\hline Present & $39(74 \%)$ & $128(87 \%)$ & \\
\hline
\end{tabular}

PTC, papillary thyroid carcinoma; WLPTC, Warthin-like variant of papillary thyroid carcinoma; HT, Hashimoto's thyroiditis.

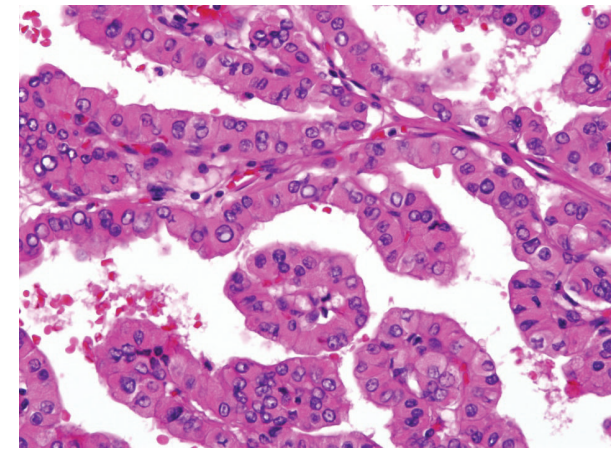

(a)

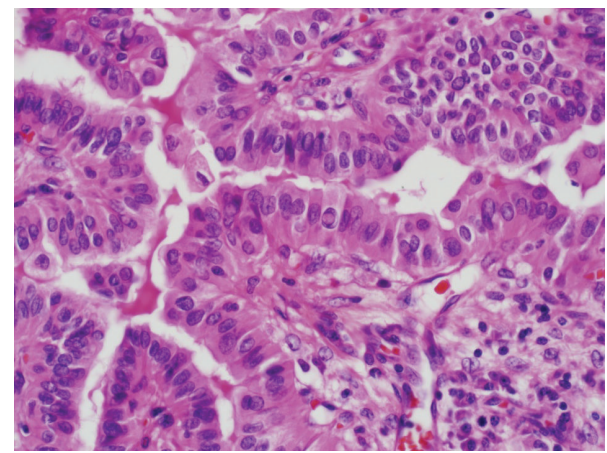

(b)

FiguRE 3: Differential diagnosis of the Warthin-like variant of papillary carcinoma includes oncocytic and tall cell variants. (a) The oncocytic variant has eosinophilic granular cytoplasm. (b) The tall cell variant contains tall cells with a height at least twice their width and eosinophilic cytoplasm. Dense stromal lymphoplasmacytic infiltration is absent in both oncocytic and tall cell variants. 
TABLE 3: Comparison of clinicopathologic characteristics between WLPTC and classic PTC coexisting with HT.

\begin{tabular}{|c|c|c|c|}
\hline Characteristic & Classic PTC with HT $(N=53)$ & WLPTC $(N=40)$ & $P$ value \\
\hline Mean age (years) & $46(25-73)$ & $46(18-77)$ & 0.892 \\
\hline Age & & & 0.833 \\
\hline$<45$ & $21(40 \%)$ & $17(43 \%)$ & \\
\hline$\geq 45$ & $32(60 \%)$ & $23(58 \%)$ & \\
\hline Sex & & & 0.081 \\
\hline Female & $52(98 \%)$ & $35(88 \%)$ & \\
\hline Male & $1(2 \%)$ & $5(13 \%)$ & \\
\hline Multifocality & & & 0.207 \\
\hline Unifocal & $25(47 \%)$ & $25(63 \%)$ & \\
\hline Multifocal & $28(53 \%)$ & $15(38 \%)$ & \\
\hline Surgery type & & & 0.611 \\
\hline Lobectomy & $12(23 \%)$ & $7(18 \%)$ & \\
\hline Total thyroidectomy & $41(77 \%)$ & $33(83 \%)$ & \\
\hline Median tumor size $(\mathrm{cm})$ & $0.7(0.3-4.5)$ & $1.0(0.4-2.2)$ & 0.285 \\
\hline pT stage & & & 0.467 \\
\hline pT1 & $34(64 \%)$ & $30(75 \%)$ & \\
\hline pT2 & $1(2 \%)$ & $1(3 \%)$ & \\
\hline pT3 & $18(34 \%)$ & $9(23 \%)$ & \\
\hline Extrathyroidal extension & & & 0.257 \\
\hline Absent & $35(66 \%)$ & $31(78 \%)$ & \\
\hline Present & $18(34 \%)$ & $9(23 \%)$ & \\
\hline $\mathrm{pN}$ stage & & & 0.833 \\
\hline pNo & $31(59 \%)$ & $22(55 \%)$ & \\
\hline $\mathrm{pN} 1$ & $22(42 \%)$ & $18(45 \%)$ & \\
\hline Preoperative diagnosis & & & 0.675 \\
\hline Atypia of undetermined significance & $2(4 \%)$ & $2(5 \%)$ & \\
\hline Suspicious for PTC & $13(25 \%)$ & $7(18 \%)$ & \\
\hline PTC & $38(72 \%)$ & $31(78 \%)$ & \\
\hline$B R A F$ mutation & & & 0.494 \\
\hline Absent & $14(26 \%)$ & $14(35 \%)$ & \\
\hline Present & $39(74 \%)$ & $26(65 \%)$ & \\
\hline
\end{tabular}

PTC, papillary thyroid carcinoma; WLPTC, Warthin-like variant of papillary thyroid carcinoma; HT, Hashimoto's thyroiditis.

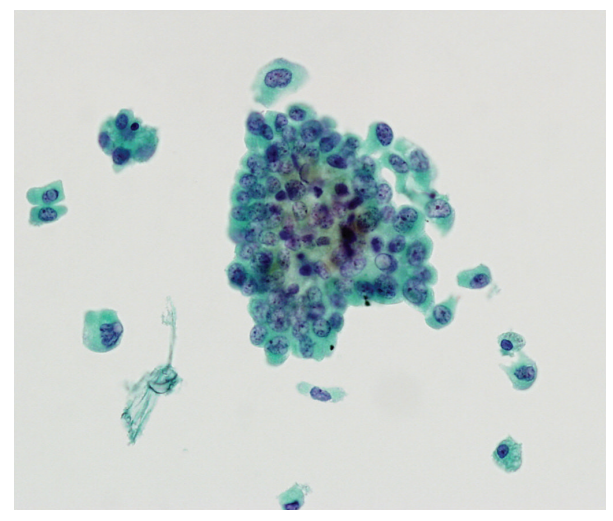

(a)

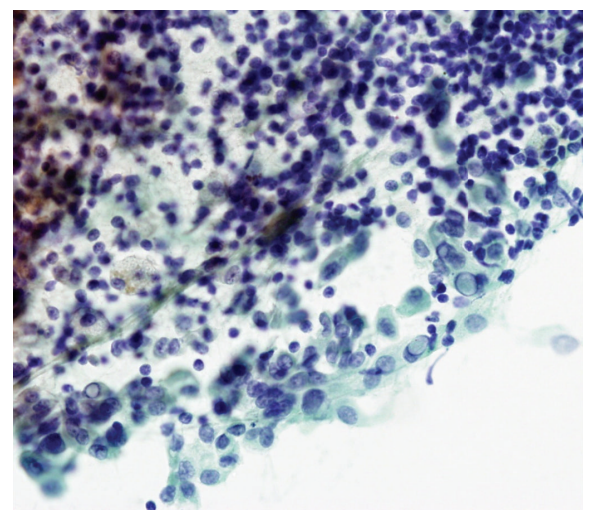

(b)

FIgure 4: ThinPrep liquid-based cytology and conventional smear of the Warthin-like variant of papillary carcinoma. (a) ThinPrep cytology shows higher cellularity and clean background compared to conventional smear. (b) In the conventional smear, there was dense lymphoplasmacytic infiltration in the cellular clusters. 
TABLE 4: Comparison of clinicopathologic characteristics between WLPTC and classic PTC microcarcinomas $(\leq 1 \mathrm{~cm})$.

\begin{tabular}{|c|c|c|c|}
\hline Characteristics of microcarcinomas & Classic PTC $(N=161)$ & $\operatorname{WLPTC}(N=25)$ & $P$ value \\
\hline Mean age (years) & $45(23-73)$ & $44(18-63)$ & 0.871 \\
\hline Age & & & 1.000 \\
\hline$<45$ & $75(47 \%)$ & $12(48 \%)$ & \\
\hline$\geq 45$ & $86(53 \%)$ & $13(52 \%)$ & \\
\hline Sex & & & 0.263 \\
\hline Female & $129(80 \%)$ & $23(92 \%)$ & \\
\hline Male & $32(20 \%)$ & $2(8 \%)$ & \\
\hline Multifocality & & & 0.196 \\
\hline Unifocal & $93(58 \%)$ & $18(72 \%)$ & \\
\hline Multifocal & $68(42 \%)$ & $7(28 \%)$ & \\
\hline Surgery type & & & 0.378 \\
\hline Lobectomy & $62(39 \%)$ & $7(28 \%)$ & \\
\hline Total thyroidectomy & $99(62 \%)$ & $18(72 \%)$ & \\
\hline Median tumor size $(\mathrm{cm})$ & $0.6(0.2-1.0)$ & $0.7(0.4-1.0)$ & 0.001 \\
\hline pT stage & & & 0.476 \\
\hline pT1 & $116(72 \%)$ & $20(80 \%)$ & \\
\hline pT2 & $0(0 \%)$ & $0(0 \%)$ & \\
\hline pT3 & $45(28 \%)$ & $5(20 \%)$ & \\
\hline Extrathyroidal extension & & & 0.476 \\
\hline Absent & $116(72 \%)$ & $20(80 \%)$ & \\
\hline Present & $45(28 \%)$ & $5(20 \%)$ & \\
\hline pN stage & & & 0.385 \\
\hline pNo & $92(57 \%)$ & $17(68 \%)$ & \\
\hline $\mathrm{pN} 1$ & $69(43 \%)$ & $8(32 \%)$ & \\
\hline Hashimoto's thyroiditis & & & $<0.001$ \\
\hline Absent & $121(75 \%)$ & $5(20 \%)$ & \\
\hline Present & $40(25 \%)$ & $20(80 \%)$ & \\
\hline Preoperative diagnosis & & & 0.521 \\
\hline Atypia of undetermined significance & $6(4 \%)$ & $2(8 \%)$ & \\
\hline Suspicious for PTC & $40(25 \%)$ & $6(24 \%)$ & \\
\hline PTC & $114(71 \%)$ & $17(68 \%)$ & \\
\hline$B R A F$ mutation & & & 0.103 \\
\hline Absent & $28(17 \%)$ & $8(32 \%)$ & \\
\hline Present & $133(83 \%)$ & $17(68 \%)$ & \\
\hline
\end{tabular}

PTC, papillary thyroid carcinoma; WLPTC, Warthin-like variant of papillary thyroid carcinoma.

\section{Conflict of Interests}

No potential conflict of interests relevant to this article was reported.

\section{Acknowledgments}

This research was supported by the Basic Science Research Program through the National Research Foundation of Korea (NRF) funded by the Ministry of Science, ICT, and future planning (2013R1A2A2A01068570).

\section{References}

[1] R. V. Lloyd, D. Buehler, and E. Khanafshar, "Papillary thyroid carcinoma variants," Head and Neck Pathology, vol. 5, no. 1, pp. 51-56, 2011.

[2] A. K.-Y. Lam, C.-Y. Lo, and K. S.-L. Lam, "Papillary carcinoma of thyroid: a 30-yr clinicopathological review of the histological variants," Endocrine Pathology, vol. 16, no. 4, pp. 323-330, 2005.

[3] V. A. Livolsi, "Papillary carcinoma tall cell variant (TCV): a review," Endocrine Pathology, vol. 21, no. 1, pp. 12-15, 2010.

[4] P. Paliogiannis, F. Attene, F. Trogu, and M. Trignano, "Warthinlike papillary carcinoma of the thyroid gland: case report and 
review of the literature," Case Reports in Oncological Medicine, vol. 2012, Article ID 689291, 4 pages, 2012.

[5] A. Erşenl, M. G. Durak, T. Canda, A. I. Sevinç, S. Saydam, and M. A. Ko,dor, "Warthin-like papillary carcinoma of the thyroid: a case series and review of the literature," Turk Patoloji Dergisi, vol. 29, no. 2, pp. 150-155, 2013.

[6] R. L. Apel, S. L. Asa, and V. A. LiVolsi, "Papillary Hurthle cell carcinoma with lymphocytic stroma. 'Warthin-like tumor' of the thyroid," The American Journal of Surgical Pathology, vol. 19, no. 7, pp. 810-814, 1995.

[7] A. D’Antonio, A. De Chiara, M. Santoro, G. Chiappetta, and N. S. Losito, "Warthin-like tumour of the thyroid gland: RET/PTC expression indicates it is a variant of papillary carcinoma," Histopathology, vol. 36, no. 6, pp. 493-498, 2000.

[8] S. Dvorkin, E. Robenshtok, D. Hirsch, Y. Strenov, I. Shimon, and C. A. Benbassat, "Differentiated thyroid cancer is associated with less aggressive disease and better outcome in patients with coexisting hashimotos thyroiditis," The Journal of Clinical Endocrinology \& Metabolism, vol. 98, no. 6, pp. 2409-2414, 2013.

[9] E. Y. Kim, W. G. Kim, W. B. Kim et al., "Coexistence of chronic lymphocytic thyroiditis is associated with lower recurrence rates in patients with papillary thyroid carcinoma," Clinical Endocrinology, vol. 71, no. 4, pp. 581-586, 2009.

[10] Y. Zhang, J. Dai, T. Wu, N. Yang, and Z. Yin, "The study of the coexistence of Hashimoto's thyroiditis with papillary thyroid carcinoma," Journal of Cancer Research and Clinical Oncology, vol. 140, no. 6, pp. 1021-1026, 2014.

[11] E. S. Cibas and S. Z. Ali, "The Bethesda system for reporting thyroid cytopathology," American Journal of Clinical Pathology, vol. 132, no. 5, pp. 658-665, 2009.

[12] S.-H. Kang, J. Y. Pyo, S.-W. Yang, and S. W. Hong, "Detection of BRAF V600E mutation with thyroid tissue using pyrosequencing: Comparison with PNA-clamping and real-time PCR," American Journal of Clinical Pathology, vol. 139, no. 6, pp. 759764, 2013.

[13] M. A. Ihle, J. Fassunke, K. König et al., "Comparison of high resolution melting analysis, pyrosequencing, next generation sequencing and immunohistochemistry to conventional Sanger sequencing for the detection of p.V600E and non-p.V600E BRAF mutations," BMC Cancer, vol. 14, no. 1, article 13, 2014.

[14] V. Marotta, A. Guerra, M. C. Zatelli et al., "BRAF mutation positive papillary thyroid carcinoma is less advanced when Hashimoto's thyroiditis lymphocytic infiltration is present," Clinical Endocrinology, vol. 79, no. 5, pp. 733-738, 2013.

[15] Y.-H. Yoon, H. J. Kim, J. W. Lee, J. M. Kim, and B. S. Koo, “The clinicopathologic differences in papillary thyroid carcinoma with or without co-existing chronic lymphocytic thyroiditis," European Archives of Oto-Rhino-Laryngology, vol. 269, no. 3, pp. 1013-1017, 2012.

[16] S. K. Kim, K.-H. Song, S. D. Lim et al., "Clinical and pathological features and the BRAFV600E mutation in patients with papillary thyroid carcinoma with and without concurrent Hashimoto thyroiditis," Thyroid, vol. 19, no. 2, pp. 137-141, 2009.

[17] K. H. Kim, K. S. Suh, D. W. Kang, and D. Y. Kang, "Mutations of the BRAF gene in papillary thyroid carcinoma and in Hashimoto's thyroiditis," Pathology International, vol. 55, no. 9, pp. 540-545, 2005.

[18] K. Kashima, S. Yokoyama, S. Noguchi et al., "Chronic thyroiditis as a favorable prognostic factor in papillary thyroid carcinoma," Thyroid, vol. 8, no. 3, pp. 197-202, 1998.

[19] F. J. Vera-Sempere, M. Prieto, and A. Camañas, "Warthinlike tumor of the thyroid: a papillary carcinoma with mitochondrion-rich cells and abundant lymphoid stroma. A case report," Pathology, Research and Practice, vol. 194, no. 5, pp. 341-347, 1998.

[20] W. J. Oh, Y. S. Lee, U. Cho et al., "Classic papillary thyroid carcinoma with tall cell features and tall cell variant have similar clinicopathologic features," Korean Journal of Pathology, vol. 48, no. 3, pp. 201-208, 2014.

[21] A. Finkelstein, G. H. Levy, P. Hui et al., "Papillary thyroid carcinomas with and without BRAF V600E mutations are morphologically distinct," Histopathology, vol. 60, no. 7, pp. 1052-1059, 2012.

[22] V. Trovisco, I. V. de Castro, P. Soares et al., "BRAF mutations are associated with some histological types of papillary thyroid carcinoma," The Journal of Pathology, vol. 202, no. 2, pp. 247-251, 2004.

[23] C.-K. Jung, S.-Y. Im, Y.-J. Kang et al., "Mutational patterns and novel mutations of the BRAF gene in a large cohort of Korean patients with papillary thyroid carcinoma," Thyroid, vol. 22, no. 8, pp. 791-797, 2012.

[24] H. S. Min, C. Lee, and K. C. Jung, "Correlation of immunohistochemical markers and BRAF mutation status with histological variants of papillary thyroid carcinoma in the Korean population," Journal of Korean Medical Science, vol. 28, no. 4, pp. 534$541,2013$.

[25] H. H. Jun, S. Kim, S. W. Hong, Y. S. Lee, H. Chang, and C. S. Park, "Warthin-like variant of papillary thyroid carcinoma: single institution experience," ANZ Journal of Surgery, 2014.

[26] R. DeLellis and E. Williams, Thyroid and Parathyroid Tumors, IARC, Lyon, France, 2004.

[27] R. Ghossein and V. A. Livolsi, "Papillary thyroid carcinoma tall cell variant," Thyroid, vol. 18, no. 11, pp. 1179-1181, 2008.

[28] Z. W. Baloch and V. A. LiVolsi, "Fine-needle aspiration cytology of papillary Hurthle cell carcinoma with lymphocytic stroma 'Warthin-like tumor' of the thyroid,' Endocrine Pathology, vol. 9, no. 4, pp. 317-323, 1998. 


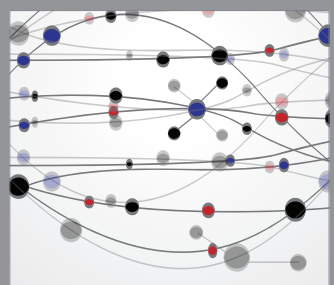

The Scientific World Journal
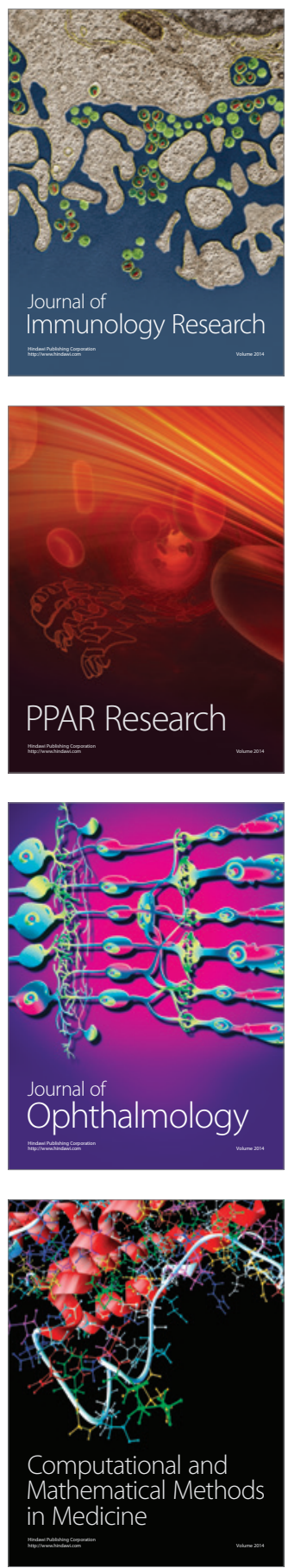

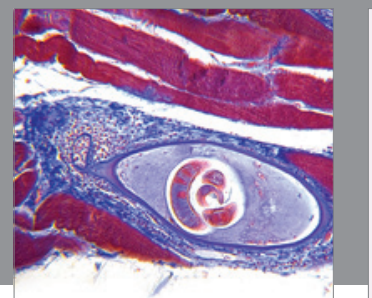

Gastroenterology

Research and Practice
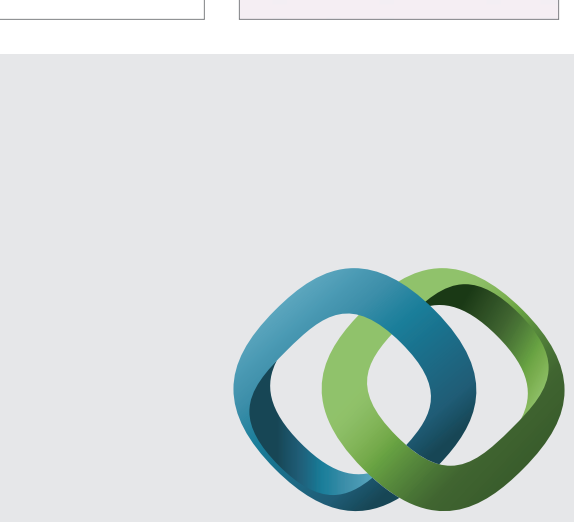

\section{Hindawi}

Submit your manuscripts at

http://www.hindawi.com
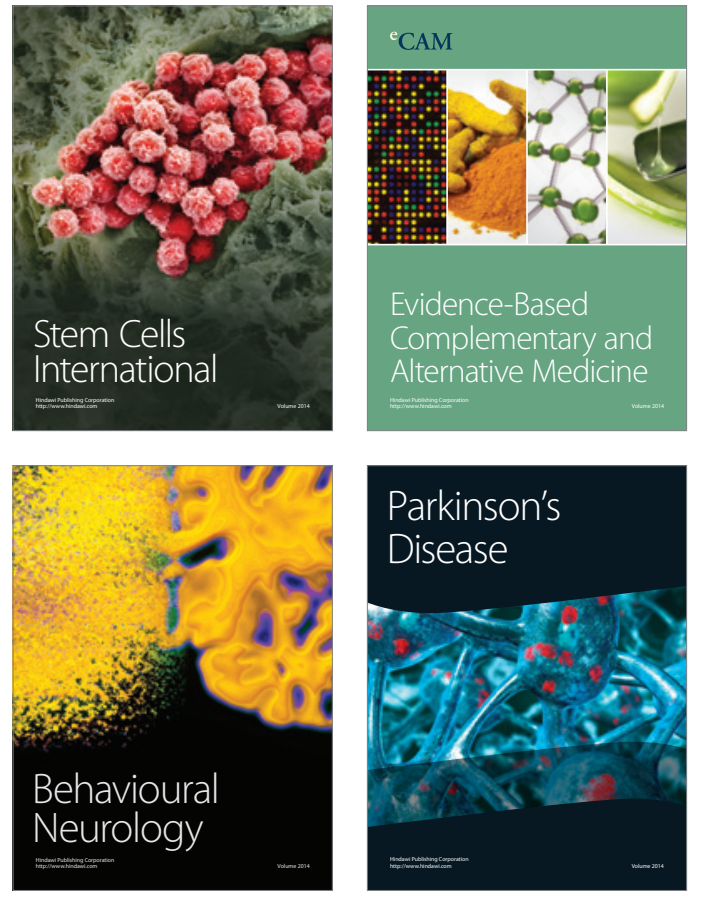
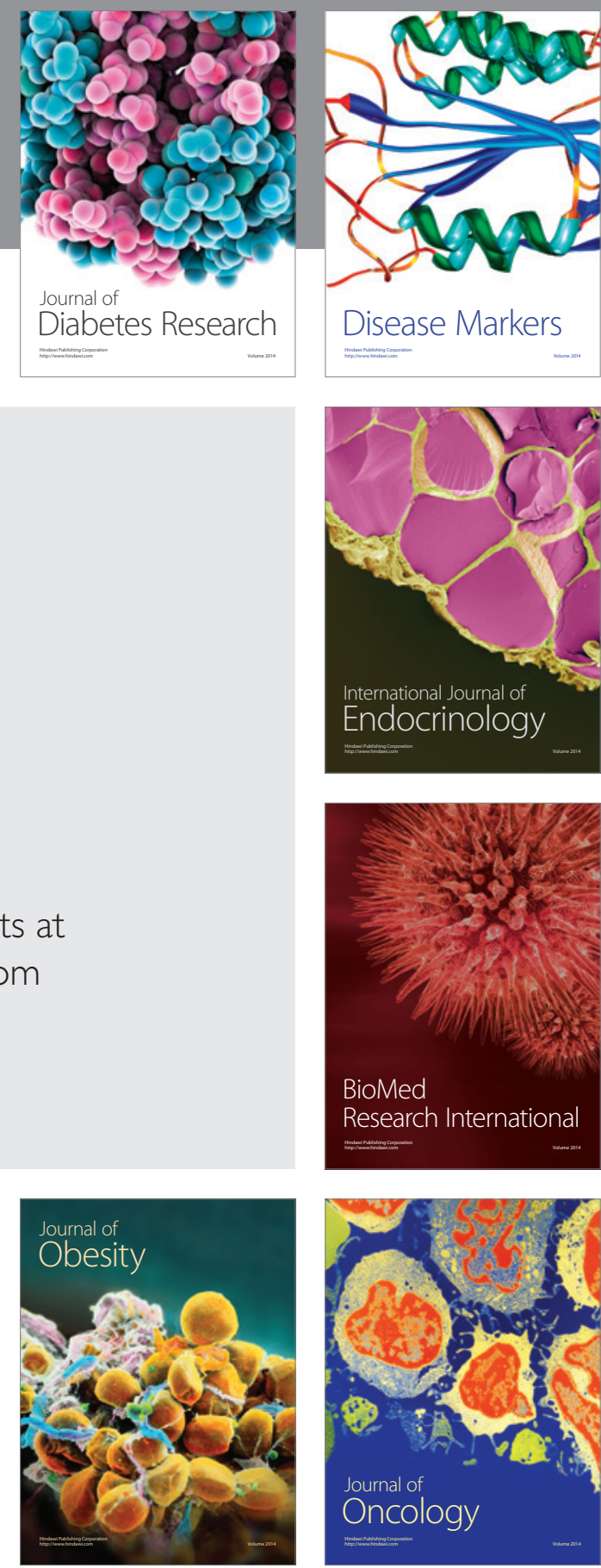

Disease Markers
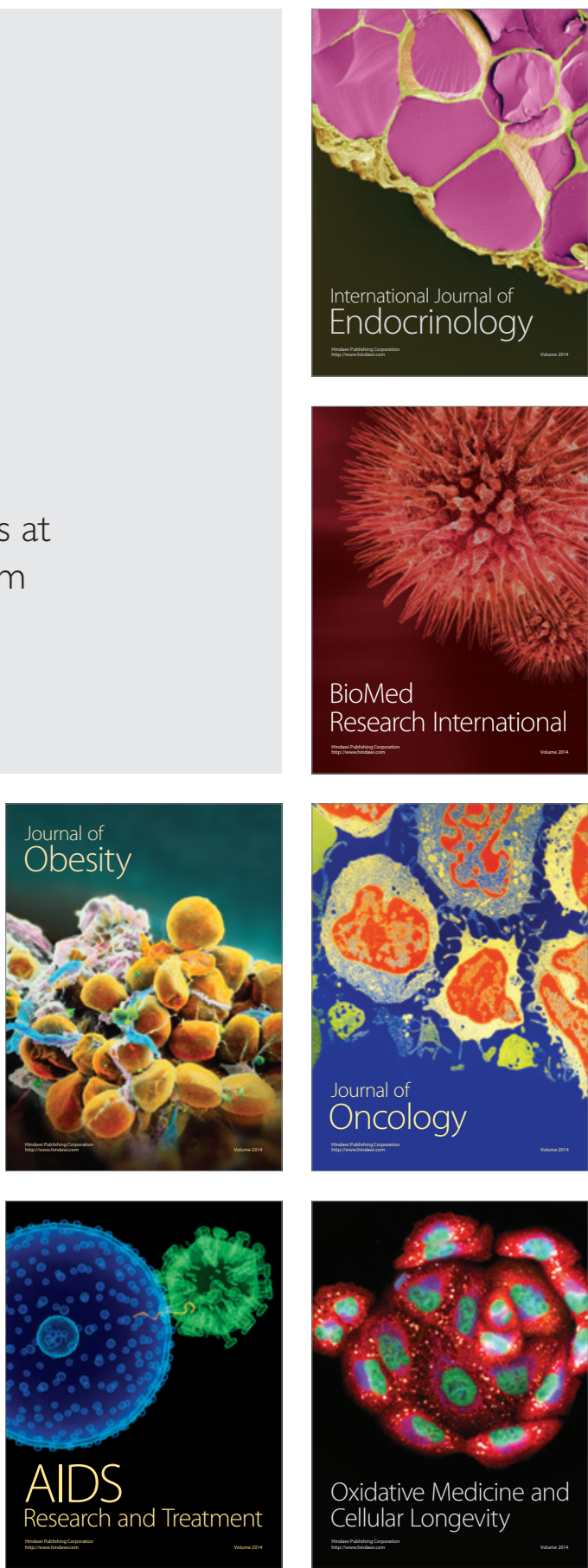